\title{
Exemplary leadership and exemplary teams: Unleashing future defence leadership potential
}

\author{
Brig Gen L.S. 'Solly' Mollo ${ }^{\bullet}$
}

\section{Introduction}

A perusal of leadership literature reflects the relatively vast amount of readily available information about leader development, all lumped under the generic heading of 'leadership training.' Yet, according to the present leadership-training debate, training is but one aspect of leader development. And from this we may deduce that much important work remains to be done on leader-development issues. Particularly so, as leader development is the imperative ingredient if organisations are to maximise the performance of human beings in pursuit of organisational goals.

Conceptually, the development of leadership can be premised on two approaches: firstly, that leadership can be taught and people are capable of learning; and, secondly, there are those who still doubt whether leadership can in fact be taught at all. The latter tend to view leadership as a set of innate abilities endowed by God and espouse the view that "great leaders are born, not made." However, social scientists have demonstrated repeatedly that leadership can be taught to those with suitable potential.

The unleashing of future leadership potential is our challenge. This requires, among other things, exemplary leaders and teams. Yet, in determining the kind of military leaders needed in the future, we must begin by position of several questions. In what context do we expect them to lead? In what roles and missions will they have to serve, and in what strategic context will they have to operate? And then to ask if the strategic environment is different, what qualities do we require in the officer expected to lead and participate in these missions?

Confronted with the complexities of our current epoch, we are painfully aware of the fact that today is by no means just a linear continuity of days past. Advances in information technology and the greater diffusion of knowledge are changing all sectors of our society. In what some scholars describe as the Revolution in Military Affairs (RMA) armed forces across the globe are confronted with the necessity to educate and develop military practitioners who are well-rounded individuals, armed with the knowledge and skills to manage legitimate violence under conditions of increased perplexity. To quote the profound insight of Richard Jennings with regard to change management, "where the

Opening address delivered on 12 September 2001 at the War and Society in Africa conference held at the South African Military Academy, 12-14 September 2001. General Mollo is Commandant, The Military Academy. 
representation of bushmen became supplanted in the 1970 s and 1980 s by a more paternalist military idiom of the bushman as a faithful collaborator, a skilled tracker with no equal. Similarly, the mature transition of the rural Zulu infantrymen from beastly barbarian to romanticised warrior is so basic a part of this picture that it scarcely needs any emphasis. Accordingly, the intertwined history of South African race attitudes and war attitudes is not without its complexities, something to which the bond between thousands of trusted African retainers or agterryers and their Boer commando masters bore witness a century or so ago.

I should like to conclude with a last piece of conjecture about the temperament of war and South African experience. This is that in our history there is no meaningful sense of war as a consuming national experience. To a considerable degree, past wars can be categorised as patchwork wars, or wars of relatively negligible impact. The World Wars were a long way off, and the losses they inflicted were comparatively light. Demographically, it could be said that the South African War mattered; but its civilian morbidity was really only a problem for the reproductive base of post-1902 Boer society. For South African society subsequently, the war at home was invariably one in which it fared reasonably well. The World Wars certainly brought no crippling war-related deprivation: less rice, less meat, less sugar, but with no threat to biltong life could go on. Perhaps only the armed rising against the apartheid order in the 1970s and 1980s eventually brought some sense of battle to an insulated home front. But, arguably, not much more than a frisson of fear, as the Pretoria housewives of 1976 joined pistol clubs.

What this all suggests is a simple conclusion about the place of modern war in this country's collective history. In a perversely reassuring way, the experience of South African war is comfortingly like the mirror of South Africa. In other words, it is essentially a story of unequal shares and differential deprivation. 
destination is unknown and conditions uncertain, emphasis must be on the seaworthiness of the vessel." Ladies and Gentleman, allow me to share what I believe are some of the issues that will determine the "seaworthiness" of this august department.

\section{Educating future military leaders: in what environment do they have to operate?}

Future SANDF missions will take place in an operational environment vastly different from before. Our soldiers will be conducting operations either amongst our own society or amongst the civil society of another country. They are already assisting the police in law and order functions, in border control operations, in combating illegal immigration, in drug traffic control, armaments control and in civil disasters, to name but a few. In the region, in peace-support operations, where the conflict is not rooted in military considerations but socio-economic and political issues, masked by ongoing conflict between fighting factions that continue to fuel interstate conflict and destabilise the region.

\section{New missions, new challenges, more skills}

What is clear is that in every case political and military considerations mingle, adding a political dimension to 'operations' practically absent in the traditional definition of that term. One of the most important lessons one can learn from the recent experiences in Somalia, Rwanda, the DRC, is that our future military leaders will need to adapt to methods of operations that can cope with the multi-dimensional challenges that go far beyond conventional warfare.

\section{Typical challenges}

One of the main challenges is that officers have to deal directly with the civilian population, with local authorities, NGO's, churches, local fighting factions, the media and police during the operation of such missions. These pose unique problems to officers: of language and communication, of having to deal with people who have a totally different mindset, who may 'negotiate' in bad faith or act out of personal interest.

A recent survey conducted by the Centre for Military Studies (Cemis), Military Academy, as part of an international study into officers experiences whilst deployed on 'operations other than war' ${ }^{\prime}$ showed that over $67 \%$ of present army officers 'sometimes' experienced difficulties in dealing with civilian counterparts. This applied particularly to their dealings with the civilian population $(55.7 \%)$, with local authorities $(41.1 \%)$ and with local combatant factions (39.2\%) with almost a fifth (18.4) of the officers experiencing difficulties in dealing with the media. ${ }^{2}$ These findings concur strongly with

\footnotetext{
${ }^{1}$ OOTW includes all peace missions, internal territorial control, border control, operations to control illegal immigration, drug trafficking, illegal weapons smuggling, disaster relief, crime prevention - all operations that do not relate directly to the protection of the country against an external aggressor.

${ }^{2}$ This survey, with the support of the then Chief of Army Force Preparation, Maj Gen L.Wessels was conducted among officers serving in the in the "sharp end" of the military, of which (27.2\%) served in the
} 
international trends where officers deployed either internally or abroad in various NATO and UN missions experience similar challenges.

Most SANDF officers claimed not to have experienced any problems in their ability to exercise their leadership during the missions in which they served. Yet many stated that their political knowledge of the situations was 'middling' $(27.6 \%)$ and could benefit from more training in languages $(27.8 \%)$, intercultural management $(25.5 \%)$, mass communication techniques $(14.6 \%)$ and military history $(14.6 \%)$. While these figures should not be seen as absolute values, they give an indication of some of the problems and shortcoming already experienced by our officers.

We can also expect that as we deploy more and more with contingents from other countries in peace-support operations, humanitarian-aid missions and the like, that our officers will come up against other kinds of difficulties. These include problems relating to interoperability, diverging interpretations of missions, divided loyalties, cultural difficulties and language problems.

According to the above-mentioned circumstances it is quite obvious that the armed forces require personnel with certain qualities and capabilities suited to the functionally changed circumstances. Clearly the task of the future military leader is now much wider than that of combat. While combat effectiveness remains the ultimate yardstick, the military leader must not only be able to evaluate daily tasks from the view of military effectiveness, but also in the light of influence on the political, ethical, linguistic and religious frameworks in which they have to operate.

\section{New missions - same skills, more knowledge}

The changed nature of war has meant that most advanced military forces have placed an increasing value on education and expertise, and have become less reliant on brute force as a criterion for winning wars. Typically this requires the future military leader to have knowledge on a far broader range of subjects, such as:

- An appropriate knowledge of foreign languages.

- A sense of cultural diversity and general understanding of foreign cultures and religions particularly those characteristics which could be a source of dispute and conflicts.

- Knowledge of regional socio-political and other factors that have resulted in the conflict.

- Knowledge and consideration of international law.

- Skills of how to negotiate and use non-violent methods to command and control.

- Effective mass communication techniques.

infantry, $(29.1 \%)$ artillery, $(9.5 \%)$ armour, $(17 \%)$ intelligence corps, $(13.3 \%)$ engineering corps and a small number in the signal corps $(2.5 \%)$. It formed part of an international study including nine different country experiences of officers deployed in OOTW. 
- Knowledge of the impact of military action on domestic and foreign affairs, economy etc.

The changing nature of military missions and the increasing participation in peacekeeping and humanitarian-aid missions has also meant that military leaders must be able to shift cognitively between applying coercive force and employing restricted force, between securing the interests of the nation and the interests of the international community. Education prepares officers to lead armed forces in such ambiguous situations. This implies that the military leader must have the ability to select proper information from a huge amount of conflicting reports in order to make the right decision.

From this it becomes increasingly clear the military leader of the future needs a broad interdisciplinary education that exposes the individual to a variety of ideas, analyses and perceptions. Higher education plays an important role in developing the capacity for independent thought and in developing the analytical abilities to understand the increasingly complex strategic environment.

\section{The Military Academy: Building and Preparing Leadership Capacity}

The Military Academy is an asset to the people of South Africa. As members of the Military Academy, we carry the responsibility to ensure that we exercise responsible trusteeship over it and enhance its capacity to contribute to the development of our country in general, and the South African National Defence Force in particular. This immense responsibility demands a commitment to face, head on, the challenges, posed by our current epoch.

The modern security environment is unpredictable. It requires a sophisticated officer corps armed with the necessary tools to confront these dynamic situations. As such the quest for excellence in education is non-negotiable. And, coupled to this, the continued professional military development of our officers is essential to ensure that we do not only have a highly qualified individual, but also a combat ready professional.

To illustrate how the quest to unleash the potential can be realised I have elected to utilise the example of the Military Academy and its role in building and preparing the leadership capacity of our young officers - our future military leaders. The endeavour in this instance is the optimal conversion of potential into a meaningful and measurable competency.

In the following section a broad overview is provided of the education and training provided to SANDF officers at the Military Academy. ${ }^{3}$ Depending on the Services

\footnotetext{
${ }^{3}$ The following section on the Military Academy is an extact of a paper presented by Lindy Heinecken titled "Preparing for operations other than war: An assessment of officer education and training in the SANDF" presented at the Conference on South Africa at War in the Twentieth Century, Military Academy, Saldanha, 4-6 September 2000.
} 
requirements certain subjects are compulsory irrespective of the subject direction for general duty (combat) officers. In the Airforce, pilots, navigators and airspace control officers are obliged to take Aeronautical Science; the Naval (combat-wet) officers, Nautical Science and the Army, infantry, armour, artillery, engineering, intelligence and air defence artillery officers, Military Geography. For some students, Military Strategy is compulsory. For the remainder, the other subject choices for all student officers irrespective of corps in the human sciences include, industrial psychology, economics, criminal and military law, military history, military geography, public and development management, computer information systems. In the natural sciences, physics, computer information systems, mathematics and military technology and in the management sciences, economics, statistics, commercial law, military management, accounting, auditing, criminal and military law. These courses are sufficiently similar to be accredited by civilian universities.

A study of the Faculty of Military Science curricula over the last decade (1990-2000) shows that the greatest change in subject content has occurred in the human sciences. The subject content of the natural and management sciences remained largely unchanged, except where this related to new technology and management practices. Within the subject of political science, there has been a move away from the typically realist approach to the study of politics and war, with a greater emphasis on political economy, civil-military relations and on the challenges facing the developing world. Industrial psychology introduced a module on peacekeeping psychology, hostage negotiations and military values and ethics. There has also been a shift in emphasis in the history curricula, with a greater emphasis on contemporary warfare, internal and low intensity conflict, with specific reference to Sub-Saharan Africa. ${ }^{4}$ Military strategy included a section of PSO as part of their national security module. While in the law department, a module on international law and the principles of law of armed conflict was introduced. These revisions are an outcome of changes in the international environment, (the end of the Cold War), changes in the national environment (constitutional requirements and changed political dispensation) and the transformation of the SA National Defence Force itself (policy guidelines, restructuring, budgetary constraints and shifting mission definition).

Currently the different subjects are contextualised in six study directions. Within each of these programmes more emphasis is given to the management of cultural diversity, labour relations, ethics and politics, security law (including principles of international law, international humanitarian law and operational law), military contemporary history and military psychology and communication skills. The knowledge acquired in these courses all relate to the type of challenges facing the future military leader, not only in a conventional capacity, but particularly in complex multi-dimensional conflict management operations in which they are expected to function.

\footnotetext{
${ }^{4}$ Approximately $33 \%$ of the third year military history course is dedicated to contemporary conventional warfare and internal conflict.
} 
Although academic education is the core business of the Military Academy, supplementing the 34 weeks of academic education is a military-training programme taking up approximately $81 / 2$ weeks per annum. The aim of the military-training branch, or the Military Development Section (MDS), is to maintain and develop the professional skills and competencies of officers through participation in various activities during military weeks and to co-ordinate functional training during the recess period.

Typically officers participate in the military weeks in a number of character building exercises. As we all know, effective leadership requires a sound education and certain character traits - most of which cannot be taught, but must be developed through a process of exposing the officer to a range of mental and physical challenges. Nobody can dispute that military service is potentially dangerous and life threatening. One of the most important officer character traits, therefore, is the physical and moral courage to control fear under conditions of stress. And here equestrian training at the Military Academy is a good test of strength of character. Few activities better test the patience, self-control, moral and physical courage, determination and perseverance of men and women than equestrian training does. Also, it is one of the few activities where race, class, gender, religion and age play no role and where the training can also be effectively used operationally.

Besides a range of adventure training exercises, officers also take part in war simulation exercises, which includes exercises in peace-mission simulation and disaster management. At the end of the three years at the Military Academy the aim is to provide the SANDF with young officers who have a broad education, but the knowledge, military skills and values required of a leader.

The knowledge and skills acquired during higher education not only produces personnel with the skills and ability to improve the functioning of the military, but also facilitates the successful transfer into a second career should the military no longer require their services. Where military service is no longer a guaranteed long-term career, members face the real threat of unemployment without some form of nationally recognised higher qualification.

Besides, many young people join the military today because they see higher education as instrumental not only for their military career, but also as an opportunity for future interorganisational mobility. This realisation is not necessarily a negative latent function. The SANDF must be concerned with the future external mobility of its personnel, especially under the present flexible service system.

It is of paramount importance that we stay focussed on the core business of the Military Academy. In educating the defenders of our democracy, the quest for excellence in education and the pursuit thereof is non-negotiable. For this reason our educators should be driven to advance learning and teaching practices to bring/keep this institution on par with international standards. They should live out the dictum that in academia not to publish means to perish. Furthermore the continued professional military development of our officers is crucial to ensure that we not only have a highly qualified individual, but 
also a combat-ready professional. The challenge of limited resources necessitates that we have to look towards creative ways of ensuring that this critical linkage between theory and practice is not severed.

At the same time we should guard against turning our institution into an ivory tower. It is unacceptable that large sections of our community are unaware of the existence of the Academy. It is crucial that we market our institution as a vital asset of our national wealth. Service to not only the military, but also the wider community should be one of our prime objectives.

\section{Leadership development of the future}

There is a growing realisation among developed nations that a physically based interpretation of war is no longer solely appropriate if one is to understand the everchanging complex security environment of the post-Cold War era. Today's conflicts are more likely to be rooted in political, psychological, social and economic causes, than merely military considerations. From this it follows that military personnel should have a sound basic knowledge of a variety of disciplines, that will enable military leaders and those under their command to think 'beyond the battlefield'. ${ }^{5}$ To quote Toffler", "the new military needs soldiers who use their brains, can deal with a diversity of people and cultures, who can tolerate ambiguity, take initiative, and ask questions, even to the point of questioning authority".

We need a more rounded military leader - one that is not just a combat leader, but also a soldier-scholar and soldier statesman. An officer who is 'operationally effective' but is skilled in handling the media and adept in the intricacies of international diplomacy. This does not imply that traditional military preparation is now obsolete, but rather, that it is insufficient and should be supplemented with other forms of knowledge. The need for a broader education in the behavioural sciences, as provided by the various programmes presented at the Military Academy, goes a long way in providing our future military leaders with the capability to make informed decisions.

Clearly we still need leaders who are trained for combat. The same skills gained in planning, training and preparing for war apply to operations other than war. The difference is greater sensitivity to the political and social environment in which they will operate - and this means a better understanding of the political context in which they have to operate.

This becomes even more important today, where officers have to operate, often in remote circumstances, without direct supervision and have to make and execute decisions independently. For this we need to transform officers from bureaucrats, to problem

\footnotetext{
${ }^{5}$ Frankel, V. 1997. "Warriors of Peace: The Next Generation of U.S. Military Leaders". Armed Forces and Society, Volume 24, No 1. Fall., p 37.

${ }^{6}$ Toffler, A. and Toffler, H. 1993. War and Anti-war: Survival as the dawn of the $21^{\text {st }}$ Century. Little, Brown Company, USA.
} 
solvers who are able to find out what is the core problem and how to solve it. More than ever before we need to empower our leaders at all levels, not only the commanders with the knowledge that will enable them to make decisions independently, with the confidence that they know the military and political implications of their decisions and actions.

Our common vision of an African Renaissance and MAP necessitates the transformation of our institutions into important assets for our sub-region. It is critical that institutions like the Military Academy assume a continental character that will make it the education facility of choice for other African armed forces. There is a need to create alliances with reputable international military education facilities. Setting up exchange programs for staff and students alike will be important not only to boost the character of the institution but also to enhance the quality of intellectual development. In doing so the environment will be created where our future leaders will flourish.

We must believe in putting people first. For that reason we must pledge support to create an environment in which our staff will be able to live out their professionalism in such a manner as to serve the higher order demands posed to us. Change should be visible. The imperatives of transformation necessitate that we face the challenge of ensuring greater diversity and representivity in our organisation. As a family we should not see this as a threat, but rather face these challenges head-on. This understanding will ensure confidence in our future leaders. The new support services system demand of each and every member the commitment to ensure that we deliver a service that will enhance our efficiency. We must be committed to transformational leadership that will allow for forums through which members can contribute their ideas towards the innovative management of our resources in a solution orientated and performance driven environment.

\section{Conclusion}

We should always remember that our milieu is Africa. We are Africans, and if we fail to expose and inculcate the important values to our future leaders we will be doing an injustice. Leadership is not a foreign concept to this Continent. Both an exemplary style and a team player inform African leadership. Values such as Ubuntu (motho ke motho ka batho/I am because we are), Seriti (aura), and Mogale/Iqhawe (warrior ethic) are part of tenets of an African leader. Like the oriental people, who say I am who I am because of you, have learnt from the west but kept their Samurai traditions, we need to expose future leaders to these traits. Globally, as a people we share so much in common. Time is the only difference. What we are discussing here today, others could have discussed it yesterday. Finally, Ladies and Gentleman I firmly believe that none of us is greater than the organisation and the country we serve. We should look forward to make contributions to achieving our higher order aims and objectives under guidance of the national leadership. Let us all ensure that the course that we will steer will weather the difficulties and uncertainties that may come our way. 